Int. J. Dev. Biol. 57: 289-298 (2013)

doi: $10.1387 / \mathrm{ijdb} .13002511$

\title{
Pathobiology of germ cell tumors - applying the gossip test!
}

\author{
LEENDERT H. J. LOOIJENGA and J. WOLTER OOSTERHUIS* \\ Department of Pathology, Erasmus MC-University Medical Center Rotterdam, Rotterdam, The Netherlands
}

\begin{abstract}
Residual mature teratoma, a frequent finding in clinical pathology since the introduction of cisplatin-based chemotherapy, put Wolter Oosterhuis on the track of germ cell tumors (GCTs). These neoplasms in the borderland between developmental biology and oncology have fascinated him ever since. He tells the story on how GCTs brought him in contact with leading investigators in the field like Ivan Damjanov, Peter Andrews, and Niels Skakkebaek. His fruitful line of research was made possible through a longstanding collaboration with Bauke de Jong and, to this day, Leendert Looijenga who joined his group as a student in 1988. Probably their most important contribution to the field of GCTs is an integrated approach to GCTs, combining epidemiology, pathology, (cyto) genetics and molecular biology, that has resulted in a pathobiology-based classification of GCTs in five types. It has clinical relevance and stimulates further research on these intriguing neoplasms and their corresponding animal models.
\end{abstract}

KEY WORDS: teratoma, teratocarcinoma, carcinoma in situ, gonadoblastoma, seminoma, dysgerminoma, germinoma, canine spermatocytic seminoma, dermoid cyst, hydatiform mole, cytogenetics, genomic imprinting, gonadal dysgenesis

Some experiences really shape your life. As a young student at the University in Groningen, I [L.L.] was in 1988 looking for a final traineeship position related to cancer research to finalize my studies in Medical Cell Biology. After some informative, although not that exciting, interviews, I was immediately intrigued by one potential supervisor: Prof. Dr. J.W. Oosterhuis, although he hardly had time to meet. He was one of the most active pathologists within the Department of Pathology, with an appreciated and impressive status of knowledge in pathology and beyond. He was constantly occupied because of the continuous phone calls (at two machines!), meetings and people lining up in front of his door. However, this was in fact, retrospectively, a supportive parameter in our developing collaboration; we could communicate with limited numbers of words and possibly even more important, limited time. Our interests matched and amplified each other, focusing on the elucidation of the patho-biology of germ cell tumors, in a clinical context, from a developmental point of view. Soon Prof. Dr. J.W. Oosterhuis became "Wolter" for me, and we started our journey. During near 25 years we had an intense interaction, in harmony, characterized by inspiration, motivation, and not being afraid of new experiences and many great challenges. I still remember our intense symposium visits where we always shared a hotel room, and enjoyed good, especially Asian food and a (single) beer, while discussing potential new ideas and especially, project proposals. Wolter proved himself as a highly dedicated, inspiring individual, interested in many different fields. His drive and discipline (in a positive sense) is absolutely a part of his success, although not always easy to combine with other (social) responsibilities. His exceptional skills in reading histological slides is a treasure source for creative and relevant hypotheses, to be tested in a laboratory setting. Never forget to ask the view of a bright, dedicated and experienced pathologist! Our common interests and Wolter's overview of more and particularly less related topics to the specific field of study allowed unexpected models and ideas to be generated and tested. I am happy that we made the journey, and that it is continuing. We are still enjoying our common interests in the combinatory study of developmental biology and cancer. In conclusion, I am more than happy that we met and did what we did. That's a fact.

\section{What is your professional training?}

I got my MD at the University of Groningen in 1972. A couple of weeks after my graduation I began to work at the Department of Pathology of the University Hospital in Groningen. The idea was to spend half a year in pathology during the waiting time before I could start my residency in surgery. That explains my Ph.D.-thesisresearch, which I did with my friend the late René Verschueren, one of the Belgians whom I was grateful to have had as a teacher. I compared iatrogenic spread of cancer cells when cutting through a malignant tumor with a scalpel and the laser beam. With tritiumlabeled Cloudman melanomas I could indeed demonstrate that

Abbreviations used in this paper: GCT, germ cell tumor; RMT, residual mature teratoma.

\footnotetext{
*Address correspondence to: J. Wolter Oosterhuis. Department of Pathology, Erasmus MC-University Medical Center Rotterdam, Rotterdam, The Netherlands. e-mail: j.w.oosterhuis@erasmusmc.nl
} 


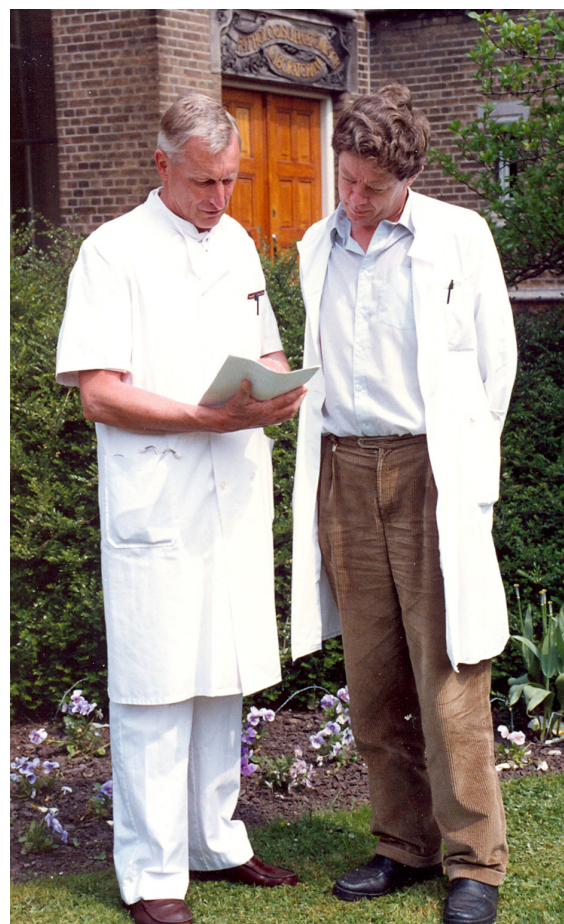

Fig. 1. Dirk Sleijfer (right) and Heimen Schraffordt Koops, driving forces behind the germ cell tumor program, in front of the Pathology Building (Groningen, 1986).

the laser caused less spread of tumor cells, more precisely radioactivity, than a scalpel (Oosterhuis, 1978). Here is where my career in surgery ended. I got so fascinated by pathology that I applied for a residency. I never regretted that decision, and enjoyed every minute in pathology.

\section{Where and how did your career in germ cell tumors (GCTs) start?}

My thesis-research brought me very much in touch with surgeons, and later surgical pathology. At the time there was a very ambitious group of surgical oncologists, headed by Jan Oldhoff. He and Heimen Schraffordt Koops, also in the department of Surgical Oncology, were the ones who treated testicular and extra-gonadal germ cell tumors in Groningen. Not the urologists, by the way. They collaborated with an equally ambitious and talented group of medical oncologists: Nanno Mulder, Dirk Sleijfer and Liesbeth de Vries. (Fig. 1) They were among the first to confirm the spectacular results of cisplatin-based chemotherapy of metastasized testicular cancer published by Einhorn in 1977 (Einhorn and Donohue, 1977) (Stoter et al., 1979). That is why I was one of the first pathologists in the Netherlands who had the chance to study residual mature teratoma (RMT). I was intrigued by the question how they came about: induction of differentiation by the chemotherapy, as many people liked to believe or selection of cancer cells with an inherent capacity of somatic differentiation. By simply comparing the histology of primary testicular non-seminomas with the histology of their metastases, I could demonstrate that RMT was almost exclusively seen in metastases derived from primaries with a teratoma component, favoring selection as the mechanism causing residual mature teratoma. (Oosterhuis et al., 1983)

Thanks to my boss, the late professor Flip Hoedemaeker, I got the opportunity to have a sabbatical year in 1980/81 (Fig. 2). I used it to further explore the causation of RMT in mouse models in Ivan Damjanov's lab at Hahnemann Medical College, Philadelphia, and in vitro using the very first embryonal carcinoma (EC-) cell lines, characterized by Peter Andrews, at that time at the Wistar Institute in Philadelphia. Indeed, nullipotent mouse embryonal carcinoma could not be induced to form RMT. These occurred only when treating pluripotent teratocarcinoma, composed of EC cells and differentiated somatic tissues (Oosterhuis and Damjanov, 1983). In Peter's lab I was the first to demonstrate that human EC cells in vitro are more sensitive for cisplatin than somatic cancer cells by a factor two to four (Oosterhuis et al., 1984).

\section{What do you consider as your most important contribution to the field?}

Back in the Netherlands, I taught second-year medical students general oncology. This forced me to read among others the classi-
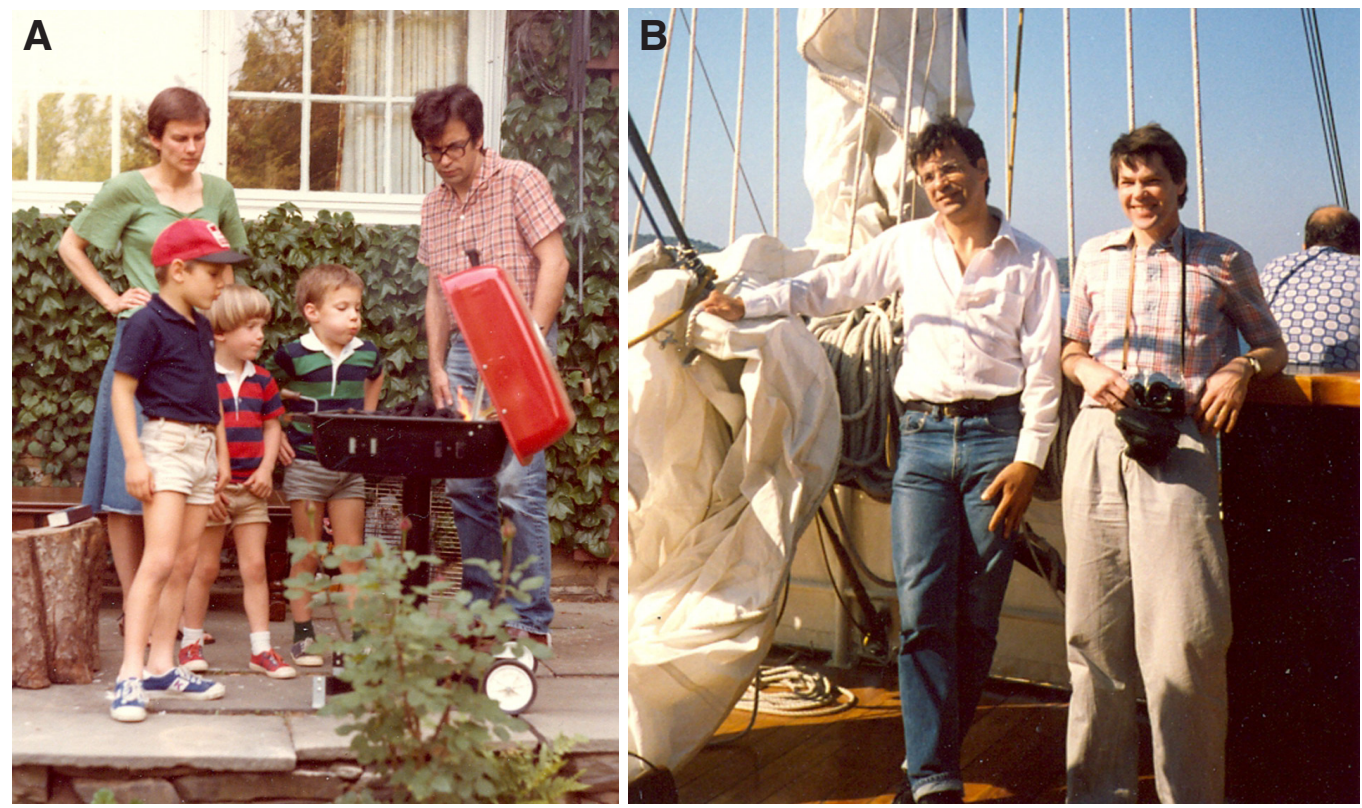

Fig. 2. Other aspects of Oosterhuis's life. (A) Many firsts during Wolter Oosterhuis' sabbatical in Philadelphia. His wife, Tine and their three boys, at that time, Gerrit, Pim (blowing) and Ekke, enjoying their first barbeque ever at Ivan Damjanov's place in Ardmore (PA), May 1981. (B) Ivan Damjanov and Wolter Oosterhuis, sailing from Dubrovnic to Cavtat. This was entertainment during a symposium on developmental biology, held in Dubrovnic (Kroatia), where Oosterhuis had the honor of presenting a poster on the Sex of Teratomas (Dubrovnic, October 1986) 
cal papers on clonal evolution by Peter Nowell and metastasis by Jos Fidler. It made me think that the highly differentiated somatic tissues in RMT might be produced by relatively early clones of tumor cells that had not yet lost the capacity to differentiate into somatic tissues. Our first approach was the study the ploidy of testicular germ cell tumors. We (Fig. 3A) found that testicular seminomas are on average hypertriploid and nonseminomas hypotriploid (Oosterhuis et al., 1989), and that CIS has the same ploidy as seminoma (de Graaff et al., 1992). To our disappointment the ploidy of primary testicular non-seminomas and RMT was the same (Oosterhuis et al., 1986), so we had to resort to karyotyping of testicular cancer and RMT to look for more subtle differences at the chromosomal level. This led to a longstanding collaboration with my friend Bauke de Jong (Fig. 3B). Supported by the Dutch Cancer Foundation we spent six weeks in Avery Sandberg's lab at Roswell Park in Buffalo: Bauke to learn karyotyping and I to learn short term culture of solid tumors. It was just after the publication by Atkin and Baker that testicular germ cell tumors are characterized by an isochromosome 12p (Atkin and Baker, 1983). Back in Groningen we were very lucky to get in touch with Sergio Castedo, a cytogeneticist from Porto. The three of us managed to karyotype many testicular germ cell tumors in a relatively short period of time: seminomas (Castedo et al., 1989c), non-seminomas (Castedo et al., 1989b), and RMTs (Castedo et al., 1989a). Often the primary tumors and RMTs were from the same patient. The answer was clear-cut: RMTs had the same karyotype as the primaries from which they were derived. Thus it appeared that RMT originates from tumor cells that are karyotypically as ugly as the rest. The lesson to be learned here was that karyotypically highly abnormal cells are capable of beautiful differentiation, as for example in the RMT, where the microscopic anatomy of colon was faithfully recapitulated (Fig. 4). However disappointing in view of our hypothesis, the result helped us to convince clinicians that RMT, no matter how highly differentiated, remains cancer, and should be surgically removed to avoid its progression to secondary non-germ cell malignancies (Gelderman et al., 1986; Oosterhuis et al., 2013).

Because of our continuous effort karyotyping germ cell tumors, we stumbled upon the finding that some germ cell tumors did have an isochromosome $12 \mathrm{p}$ and others did not (Castedo et al., 1989c). Those which did not were divided in tumors that were yet near triploid and had other chromosomal aberrations involving the short arm of chromosome 12. And there were germ cell tumors, for example of the testis of infants, and dermoid cysts of the ovary, which were diploid and lacked abnormalities of chromosome 12 (Oosterhuis et al., 1990).

Scrutinizing Gonzalez Crussi's fascicle on extra-gonadal germ cell tumors in the second series of AFIP atlases (Gonzalez-Crussi, 1982), it struck me that there are two types of germ cell tumors. Those that do have a seminoma-component and those that do not. The former occur only in the gonads, the anterior mediastinum and the midline of the brain. My prediction was that those tumors were the ones that would have an $\mathrm{i}(12 \mathrm{p})$ regardless of the anatomical
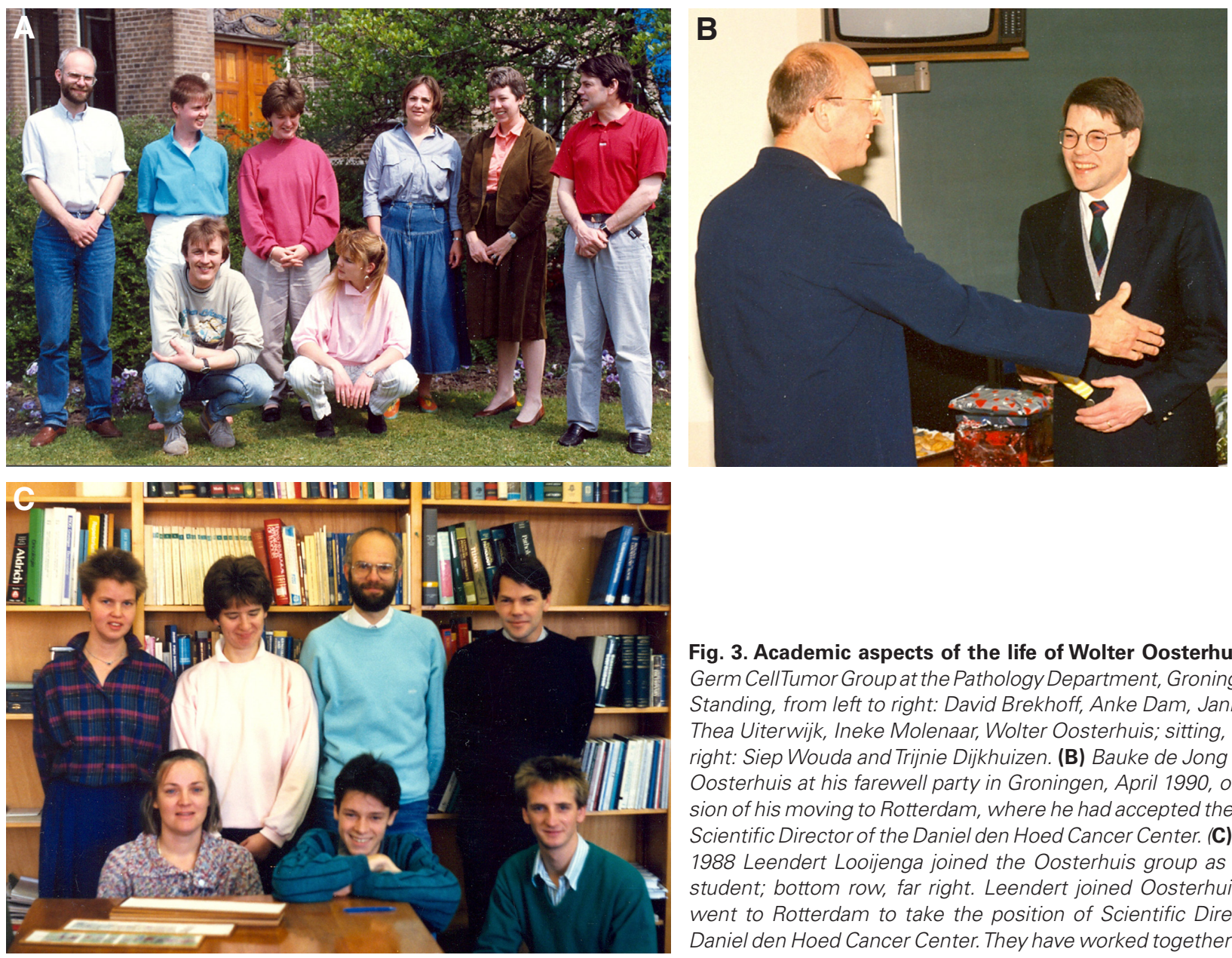

Fig. 3. Academic aspects of the life of Wolter Oosterhuis. (A) The Germ CellTumor Group at the Pathology Department, Groningen, (1986). Standing, from left to right: David Brekhoff, Anke Dam, Janneke Buist, Thea Uiterwijk, Ineke Molenaar, Wolter Oosterhuis; sitting, from left to right: Siep Wouda and Trijnie Dijkhuizen. (B) Bauke de Jong addressing Oosterhuis at his farewell party in Groningen, April 1990, on the occasion of his moving to Rotterdam, where he had accepted the position of Scientific Director of the Daniel den Hoed Cancer Center. (C) In October 1988 Leendert Looijenga joined the Oosterhuis group as a graduate student; bottom row, far right. Leendert joined Oosterhuis when he went to Rotterdam to take the position of Scientific Director of the Daniel den Hoed Cancer Center. They have worked together ever since. 
localization. I was therefore a bit jealous, but not surprised when Paula Dal Cin published the karyotype of a germ cell tumor of the anterior mediastinum with an i(12p) (Dal Cin et al., 1989), which she showed at a symposium on germ cell tumors in Groningen in 1989 that I had organized as a satellite of the meeting of developmental biologists in Utrecht, The Netherlands. It was very gratifying that Bauke and I got involved in the publication of germ cell tumor of the brain, diagnosed at the University Hospital in Utrecht, and karyotyped in Amsterdam by Rosalyn Slater, which had an i(12p) (de Bruin et al., 1994).

This is a long, and somewhat meandering introduction to my answer to your question on what I consider as my most important contribution to the field. Our (Bauke de Jong, you and me) studies of the chromosomal constitution and genomic imprinting of germ cell tumors (van Gurp et al., 1994) led us to propose a comprehensive classification of germ cell tumors in 1997 in the issue of Cancer Genetics and Cytogenetics, in celebration of Dr. Avery A. Sandberg's 75th birthday (Oosterhuis et al., 1997). In our invited review in Nature Reviews Cancer in 2005 (Oosterhuis and Looijenga, 2005) we elaborated on this classification (Table 1), which is now gaining wider acceptance. The strength of this classification is that it includes epidemiology and biology of germ cell tumors, in addition to morphology. Our work has also provided clues as to the molecular mechanisms causing germ cell tumors. Spermatocytic seminoma which we had earlier shown to be negative for PLAP as opposed to seminoma (Dekker et al., 1992) is a beautiful example. Karyotyping these rare tumors we found an extra chromosome 9 as the only chromosomal characteristic (Rosenberg et al., 1998). Your studies clarified that DMRT1, in a small amplified region on chromosome 9, plays a crucial role in the causation of these tumors. DMRT1 proved to be useful in the differential diagonosis of seminoma and spermatocytic seminoma, since it is specifically expressed in spermatocytic seminoma, both in humans (Looijenga et al., 2006) and in dogs.

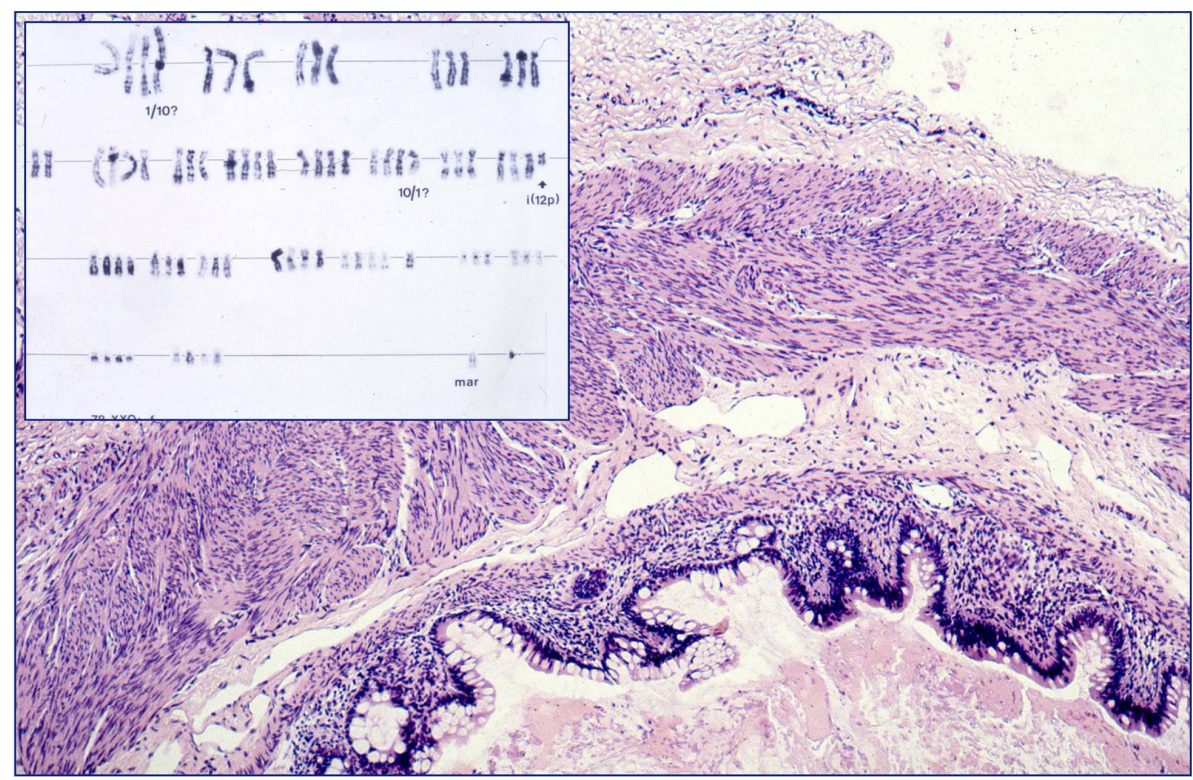

Fig. 4. Ugly karyotype, yet organoid differentiation. Residual teratoma after cisplatin-based chemotherapy showing microscopical anatomy of colon: tunica muscularis (two layers), submucosa, muscularis mucosae, lamina propia and colonic mucosal epithelium. Inset: highly abnormal, near triploid karyotype with characteristic 12p isochromosome (Castedo et al., 1989a).
This brings me to an important spin off from our need for fresh tumor tissue for karyotyping. It forced us to collect tumor tissue at the operation theatres, first in the three Northern provinces of the Netherlands, and from the time you and I moved together to the Daniel den Hoed Cancer Center in 1990 (Fig. 3C and 5A), in Rotterdam and the South-Western part of the Netherlands. It has resulted in one of the finest collections of freshly frozen germ cell tumors. It is a gold mine, not only for us, also for scientists and clinicians all over the world with whom we have had fruitful collaborations, using this tumor-bank. It was thanks to the continuous support of clinicians and their patients that we were able to create this bank.

\section{What is your most preferred model for the pathogenesis of GCTs?}

It does not come as a surprise to you: there is not one model for the pathogenesis of GCTs. Each of the five Types we distinguish has its own pathogenesis. Although there is still a lot to be learned, we know quite a bit about the pathogenesis of Types II through V. Our contribution to the understanding of spermatocytic seminoma (Type III tumors) I have already mentioned.

As for Type II tumors of the testis, Niels Skakkebæk (Fig. 5B) and his group have established the crucial role of carcinoma in situ (CIS, synonym: IGCNU or TIN) in the pathogenesis of Type II tumors of the testis, and its origin during the embryonic development of the patient (Skakkebaek et al., 1987). Our contribution recently has been through the study of germ cell tumors originating in dysgenetic gonads, which we have dubbed the "earliest accessible stage" in the development of these tumors. Indeed, study of tumors originating in dysgenetic gonads has shown the importance of delayed maturation of primordial germ cells/gonocytes, because of the window it creates for co-expression of OCT3/4, TSPY and SCF (also known as KITLG) in the transformation of delayed gonocytes into pre-CIS, and CIS cells. (Kersemaekers et al., 2005) (Cools et al., 2011) (Oosterhuis et al., 2011) We have also made the case that (low level) amplification of the short arm of chromosome 12 appears in CIS-cells only when they become independent from their feeder cells, the Sertoli cells in the seminiferous tubules (Rosenberg et al., 2000). Obvious as it may seem, we had to convince our colleagues that the default pathway in the development of Type II germ cell tumors is seminoma (unique to humans, by the way), and that non-seminomas are the result of reprogramming of a seminomatous precursor cell, be it a CIS cell or a seminoma cell (in a primary tumor or a metastasis) to a pluripotent EC cell (Oosterhuis and Looijenga, 1993). In my opinion, and we have published data supporting this contention, most nonseminomas originate within seminiferous tubules as intra-tubular non-seminoma. Peculiarly intra-tubular non-seminoma is almost exclusively composed of EC (Oosterhuis et al., 2003). This raises the question about the factors which inhibit differentiation within the tubules, and conversely, those which stimulate differentiation upon exposure of infiltrating 

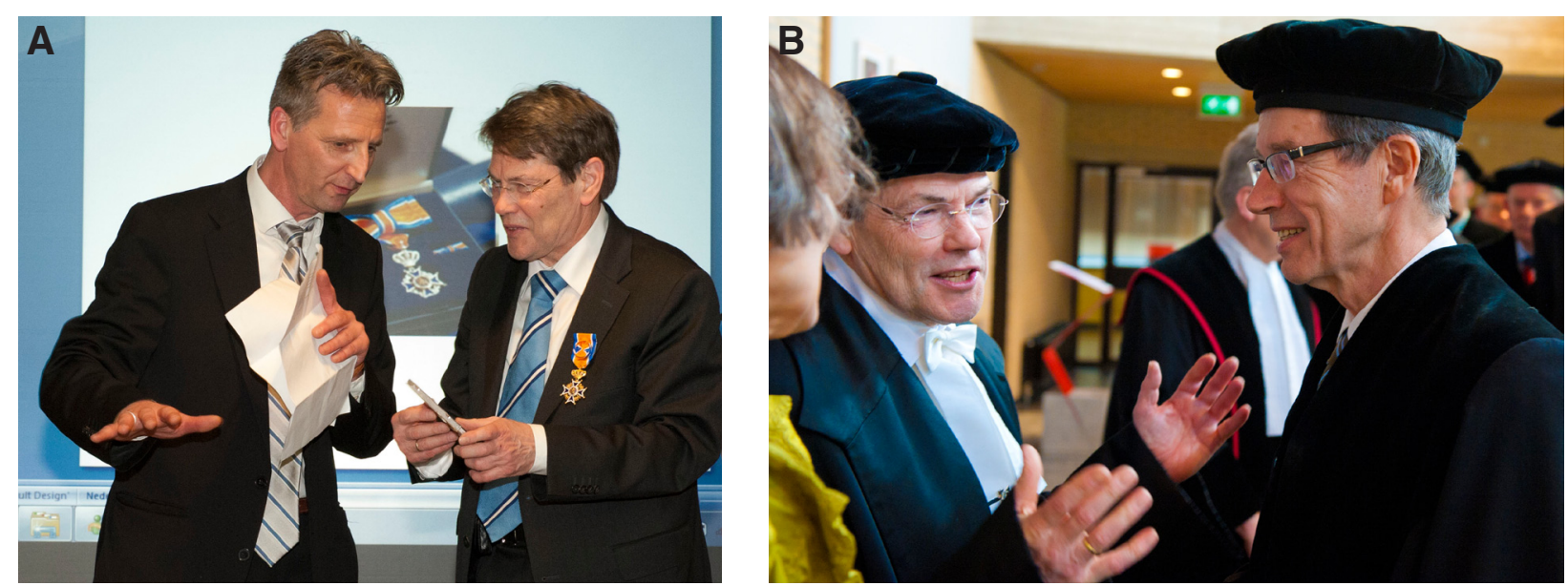

Fig. 5. Academic achievements. (A) Growing older: Leendert and Wolter at the party on the occasion of Wolter's retirement (still compulsory at age 65 in the Netherlands); Wolter was being appointed Officier in de Orde van Oranje Nassau, hence the colourful decoration. Since his retirement, he has joined Leenderts group at the Department of Pathology in the Josephine Nefkens Institute, part of the Erasmus University Medical Center in Rotterdam (March 31, 2011). (B) Niels Skakkebæk, one of the speakers at Wolter's farewell symposium, splendidly organized by Leendert (March 31, 2011).

EC-cells to the extra-tubular micro-environment (Fig. 6) We know very little about how the Type I tumors originate. Even the cell of origin of these tumors is a matter of debate. Because of their retained bi-parental or partly erased genomic imprinting, we have favored the view that they are derived from a precursor cell, which is developmentally somewhere between an embryonic stem (ES) cell and a primordial germ cell/gonocyte (Oosterhuis et al., 2007). Recent insight into the genes that can reprogram somatic cells to pluripotency, and in particular the observation that OCT3/4 by itself is capable of doing that (Kim et al., 2009), forces one to rethink existing concepts on the origin of extragonadal germ cell tumors. It is conceivable, as suggested by Scotting, that primi-

TABLE 1

THE FIVE TYPES OF GERM CELL TUMORS (OOSTERHUIS AND LOOIJENGA, 2005)

\begin{tabular}{|c|c|c|c|c|c|c|c|}
\hline Type & $\begin{array}{l}\text { Anatomical } \\
\text { site }\end{array}$ & Phenotype & Age & $\begin{array}{l}\text { Originating } \\
\text { cell }\end{array}$ & $\begin{array}{l}\text { Genomic } \\
\text { imprinting }\end{array}$ & Genotype & $\begin{array}{l}\text { Animal } \\
\text { model }\end{array}$ \\
\hline I & $\begin{array}{l}\text { Testis/ovary/ } \\
\text { sacral region/ } \\
\text { retroperitoneum/ } \\
\text { mediastinum/ } \\
\text { neck/midline } \\
\text { brain/other rare } \\
\text { sites }\end{array}$ & $\begin{array}{l}\text { (Immature) } \\
\text { teratoma/ } \\
\text { yolk-sac tumour }\end{array}$ & $\begin{array}{l}\text { Neonates and } \\
\text { children }\end{array}$ & $\begin{array}{l}\text { Early PGC/ } \\
\text { gonocyte }\end{array}$ & $\begin{array}{l}\text { Biparental, } \\
\text { partially erased }\end{array}$ & $\begin{array}{l}\text { Diploid (teratoma). } \\
\text { Aneuploid (yolk-sac } \\
\text { tumour): gain of } \\
\text { 1q, 12(p13) and 20q, } \\
\text { and loss of 1p,4 } \\
\text { and 6q }\end{array}$ & $\begin{array}{l}\text { Mouse } \\
\text { teratoma }\end{array}$ \\
\hline \multirow[t]{5}{*}{$\|$} & Testis & $\begin{array}{l}\text { Seminoma/ } \\
\text { non-seminoma }\end{array}$ & $\begin{array}{l}>15 \text { years } \\
\text { (median age } \\
35 \text { and } 25 \text { years) }\end{array}$ & PGC/gonocyte & Erased & $\begin{array}{l}\text { Aneuploid } \\
\text { (+/- triploid): } \\
\text { gain of } X, 7,8,12 p \\
\text { and } 21 ; \text { and loss of } \\
Y, 1 p, 11,13 \text { and } 18\end{array}$ & Not available \\
\hline & Ovary & $\begin{array}{l}\text { Dysgerminoma/ } \\
\text { non-seminoma }\end{array}$ & $>4$ years & PGC/gonocyte & Erased & Aneuploid & Not available \\
\hline & Dysgenetic gonad & $\begin{array}{l}\text { Dysgerminoma/ } \\
\text { non-seminoma }\end{array}$ & Congenital & PGC/gonocyte & Erased & Diploid/tetraploid & Not available \\
\hline & $\begin{array}{l}\text { Anterior } \\
\text { mediastinum } \\
\text { (thymus) }\end{array}$ & $\begin{array}{l}\text { Seminoma/ } \\
\text { non-seminoma }\end{array}$ & Adolescents & PGC/gonocyte & Erased & Diploid/tri-tetraploid & Not available \\
\hline & $\begin{array}{l}\text { Midline brain } \\
\text { (pineal gland/ } \\
\text { hypothalamus) }\end{array}$ & $\begin{array}{l}\text { Germinoma/ } \\
\text { non-seminoma }\end{array}$ & $\begin{array}{l}\text { Children (median } \\
\text { age } 13 \text { years) }\end{array}$ & PGC/gonocyte & Erased & Diploid/tri-tetraploid & Not available \\
\hline III & Testis & $\begin{array}{l}\text { Spermatocytic } \\
\text { seminoma }\end{array}$ & $>50$ years & $\begin{array}{l}\text { Spermatogonium/ } \\
\text { spermatocyte }\end{array}$ & $\begin{array}{l}\text { Partially complete } \\
\text { paternal }\end{array}$ & Aneuploid: gain of 9 & $\begin{array}{l}\text { Canine } \\
\text { seminoma }\end{array}$ \\
\hline IV & Ovary & Dermoid cyst & Children/adults & Oogonia/oocyte & $\begin{array}{l}\text { Partially complete } \\
\text { maternal }\end{array}$ & $\begin{array}{l}\text { (Near) diploid, } \\
\text { diploid/tetraploid, } \\
\text { peritriploid (gain of X, } 7 \text {, } \\
12 \text { and 15) }\end{array}$ & $\begin{array}{l}\text { Mouse } \\
\text { gynogenote }\end{array}$ \\
\hline V & Placenta/uterus & Hydatidiform mole & Fertile period & $\begin{array}{l}\text { Empty ovum/ } \\
\text { spermatozoa }\end{array}$ & $\begin{array}{l}\text { Completely } \\
\text { paternal }\end{array}$ & Diploid (XX and $X Y)$ & $\begin{array}{l}\text { Mouse } \\
\text { androgenote }\end{array}$ \\
\hline
\end{tabular}

PGC, primordial germ cell. Modified with permission from Oosterhuis and Looijenga (2005). 


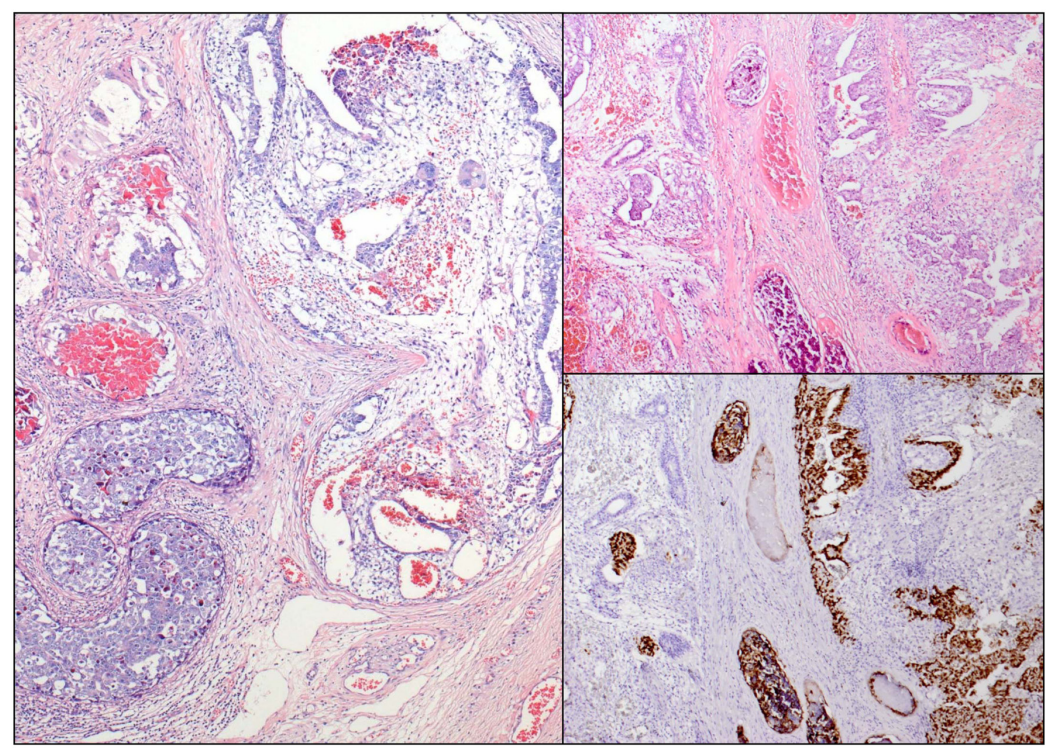

Fig. 6. Intratubular nonseminoma does not differentiate. Left panel shows haematoxylin and eosin stain of intratubular nonseminoma solely composed of embryonal carcinoma, the undifferentiated stem cell population of nonseminoma, and neoplastic counterpart of embryonic stem cells (left lower corner). The surrounding invasive tumor shows extensive differentiation with somatic, yolk sac and trophoblastic elements. In the right upper panel a similar picture, with partly necrotic, pure embryonal carcinoma within seminiferous tubules in the middle of the photograph, and differentiating invasive embryonal carcinoma on both sides. In the right lower panel the embryonal carcinoma cells can be easily recognized from their nuclear expression of OCT3/4.

tive cells reactivate OCT3/4, and thereby give rise to germ cell tumors (Tan and Scotting, 2013). The finding that human ES cells can in vitro differentiate into the germ cell lineage (Clark et al., 2004), and our observation that also in non-seminomas early differentiation into the germ lineage can occur (Honecker et al., 2006) suggests that via this mechanism not only Type I, but also Type II tumors might develop. This discussion has the danger of becoming semantic, of course. The tumors that develop are in the end germ cell tumors. The question to be resolved is: do they originate from germ cells displaced during embryogenesis, or from germ cells that via activation of pluripotency are produced in various extra-gonadal localizations?

\section{What do you consider important lessons from animal models?}

The most fascinating lesson I have learned is that Type II germ cell tumors are unique for humans. I mean the germ cell tumors composed of neoplastic primordial germ cells/gonocytes (seminoma/dysgerminoma/germinoma) and the pluripotent tumors derived from them through reprogramming of the transformed primordial germ cell: nonseminoma, which is in fact a neoplastic caricature of embryonic development. To the best of my knowledge these tumors do not exist in animals neither spontaneously, nor induced. The various murine teratoma/teratocarcinoma models, extensively studied by Roy Stevens, Barry Pierce, Ivan Damjanov and Davor Solter (Damjanov and Solter, 1974) (Solter, 2006) are not models of Type II germ cell tumors of humans, as they do not develop via a "seminomatous precursor-stage". CIS as precursor of nonseminoma of the human testis is, just as an example, nicely illustrated in figure 1e of Davor Solter's review (Solter, 2006) with carcinoma in situ in the seminiferous tubules adjacent to the nonseminoma composed of embryonal carcinoma. The murine teratomas/teratocarcinomas are probably derived from either ES cells or primitive germ cells that are immediately reprogrammed to pluripotency (Walt et al., 1993). Not surprisingly tumors resulting from ectopic transplantation of murine or human ES or PGC cells have the same morphology as the aforementioned murine models (Evans and Kaufman, 1981) (Matsui et al., 1992) (Thomson et al., 1998). Rather these murine tumors are models for human Type I tumors, which occur both in the gonads and in extra-gonadal localizations, but at a much younger age, generally speaking under age 6 (Stang et al., 2012), and in a much wider distribution than the extra-gonadal Type II germ cell tumors, which are confined to the anterior mediastinum/ thymus and the midline of the brain. There are many arguments for questioning the generally accepted view that these mouse tumors are models for Type II tumors. We have summarized them in our review in Nature Reviews Cancer (Oosterhuis and Looijenga, 2005). An accidental finding in the lab provided one of those arguments. During my sabbatical in Ivan Damjanov's lab he taught me how to produce embryo-derived teratomas/teratocarcinomas. Back in Groningen I produced many of them for several purposes. My take rate was sometimes on the low side. The protocol prescribed that the transplanted mice had to be sacrificed after six weeks, regardless of take. I just could not do it, and violated the protocol by leaving the mice without take alive, with the vague idea that I could use them one way or another. To my surprise virtually all these mice developed big tumors after several months to a year. These appeared to be parietal yolk sac tumors (van Berlo et al., 1990). Thus mimicking in the mouse the clinical observation that Type I tumors of the sacral area may recur as yolk sac tumor if they are incompletely removed (Oosterhuis et al., 1993). The so-called seminomas in animals are more similar to human spermatocytic seminomas, the Type III tumors. We have studied them in dogs (Looijenga et al., 1994) and found that they express DMRT1 like the human spermatocytic seminomas, as I mentioned earlier. We propose that dermoid cysts of the ovary (Type IV tumors) are mimicked by gynogenotes, which develop somatic tissues mainly, with severe impairment of the placental development, and the hydatiform moles (Type $\mathrm{V}$ tumors) by androgenotes, in which virtually only placenta is developed and hardly somatic tissues (McGrath and Solter, 1983b) (McGrath and Solter, 1983a) (Surani et al., 1986). Quite anecdotic, my interest in the role of genomic imprinting in the developmental potential of germ cell tumors was triggered by the nuclear transfer experiments by Jim McGrath and Davor Solter. It is funny that these experiments were under way in the Wistar Institute in Philadelphia when I was there with Peter Andrews trying to kill embryonal carcinoma cells with cisplatin. At the time I was unaware of the ground-breaking work being done one floor up (Fig. 7.)

\section{What is in your opinion the most relevant question to be answered related to $\mathrm{GCTS}$ ?}

As I mentioned earlier, the cell of origin of extra-gonadal germ cell tumors is an intriguing question. The initiating events 
of Type II germ cell tumors are only partly understood. Genome wide association studies in particular raise new questions about the interplay between constitutional variants of the genome that condition the microenvironment in the developing gonads and influence susceptibility to early initiating events in primordial germ cells (Kanetsky et al., 2009) (Rapley et al., 2009). Despite substantial efforts by us and others, we still don't know which genes on 12p favor progression of Type II germ cells tumors.

Our work has also contributed to insight into the treatment resistance of these tumors (Mayer et al., 2003) (Mayer et al., 2011), but frankly, we still don't know the molecular basis of the
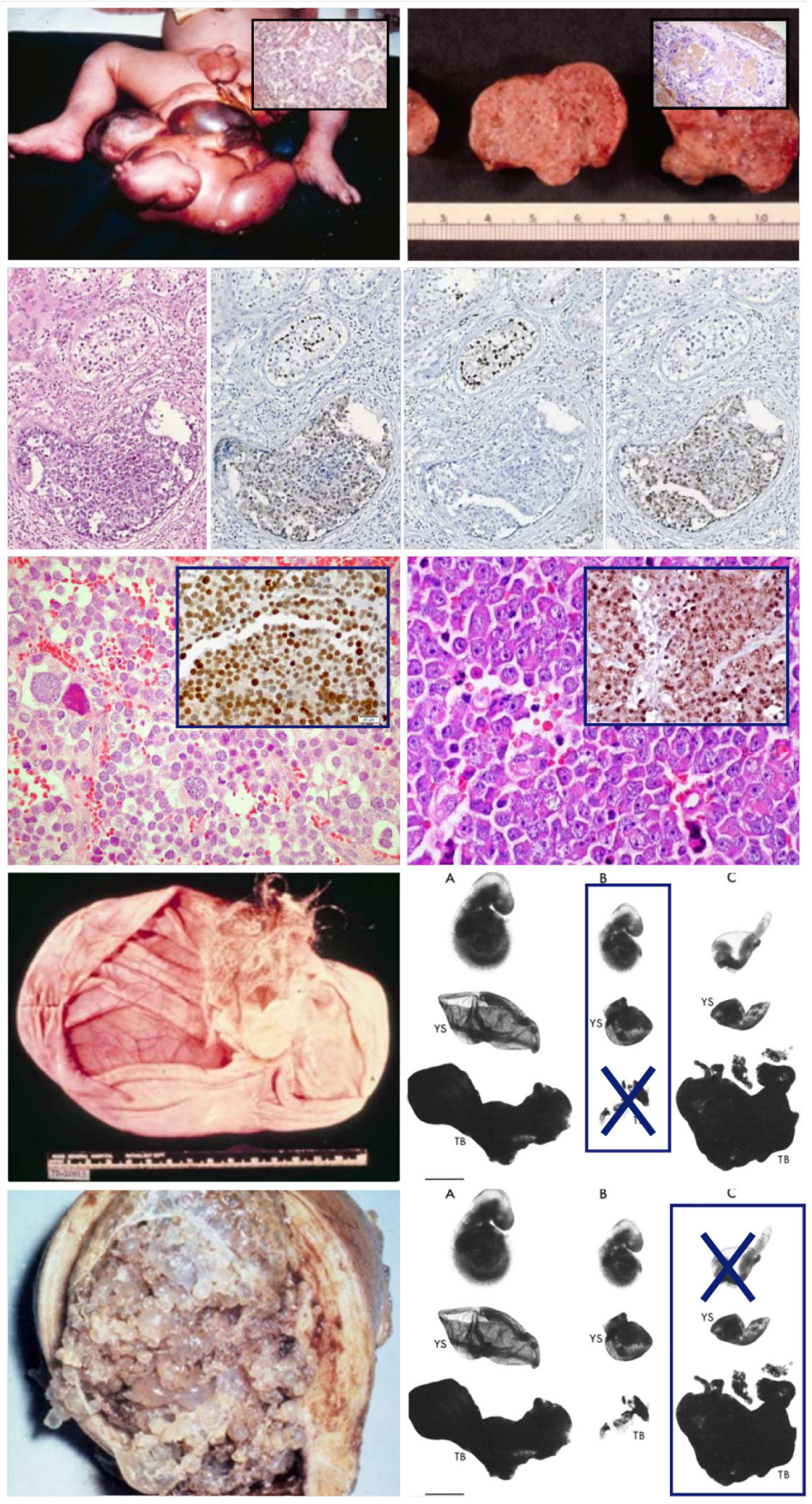

exquisite sensitivity of Type II tumor for cisplatin, and why the reprogramming of a seminomatous cell makes it resistant to radiation therapy.

\section{Do you think that the newest high throughput methods will contribute to understanding the pathogenesis of GCTs?}

I have no doubt that high throughput analyses will make important contributions. Work by Mike Stratton for example has shown that Type II germ cell tumors have very few mutations (Bignell et al., 2006). We were not surprised, but now we know for sure. One of the most frequent mutations he found, by the way, is in CKIT, and that one, we knew already, as it was found through hypothesis-driven research (Looijenga et al., 2003a; Biermann et al., 2007). Similarly, we and others did expression analysis of seminoma and embryonal carcinoma and found that one the most expressed genes was OCT3/4 (Cheng et al., 2007; Gillis et al., 2011), which we had already discovered through hypothesis-driven investigation (Looijenga et al., 2003b). Genome-wide Association Studies (GWAS) on the other hand, showing variants of SCF (KITLG) increasing the risk of Type II germ cell tumors, produce results which could hardly be obtained otherwise (Kanetsky et al., 2009) (Rapley et al., 2009). Next generation sequencing might be the tool to unravel what is happening on $12 p$, and finally give us a handle on which genes drive the progression of Type II germ cell tumors. I have high hopes that your work on

Fig. 7. Human germ cell tumors Type I-V, side by side with their animal models, apart from Type II, which is unique to humans. Type I, teratomas/yolk sac tumors in humans typically below the age of six (Stang et al., 2012). Upper row left: sacral teratoma of newborn as an example of a Type I tumor (Oosterhuis et al., 1993) first described by fetoscopists in ancient Egypt as "foot in the middle" that brings prosperity to the land (Wheerler, 1983) (inset: recurrence as yolk sac tumor). Upper row right: embryo-derived teratocarcinoma (inset: late appearing parietal yolk sac tumor, here with rare trophoblastic elements as well) (van Berlo et al., 1990). Type II, the seminomas/ dysgerminomas/germinomas and nonseminomas of adults, unique for humans. Shown as an example in the second row, early stages of a testicular nonseminoma: four photographs from left to right, $H$ and E, OCT3/4, SOX17 and SOX2. The four photographs show the distinguishing phenomenon of reprogramming of the neoplastic primordial germ cells/gonocytes of carcinoma in situ (CIS) (upper tubule) into intratubular embryonal carcinoma (lower tubule, extended by the tumor). CIS cells co-express OCT3/4 and SOX17; EC cells co-express OCT3/4 and SOX2 (de Jong et al., 2008b). Type III, spermatocytic seminoma, exclusively occurring in the testis. Third row left: human spermatocytic seminoma (inset: nuclear staining for DMRT1) (Looijenga et al., 2006); third row right: so-called seminoma of a dog, which is DMRT1-positive (inset), consistent with it being a model for human spermatocytic seminoma, rather than human seminoma (Looijenga et al., 1994). Type IV, fourth row left: dermoid cyst of the ovary, solely composed of fully differentiatied somatic tissues such as hair and skin, characterized by a bimaternal genomic imprinting pattern; fourth row right: gynogenote with bimaternal genomic imprinting, developing somatic tissue of the embryo proper, but no throphoblast (frame) (Surani et al., 1986). Type V, bottom row left: uterus with complete mole, solely composed of trophoblastic tissue, resembling a bunch of grapes, characterized by a bipaternal genomic imprinting pattern; bottom row right: androgenote with bipaternal genomic imprinting pattern, developing placenta, but no somatic tissue of the embryo proper (frame) (Surani et al., 1986). 
miRNA profiling of germ cell tumors will give us new insights into the complex biology of these tumors, and perhaps new markers for early diagnosis and clinical management (Gillis et al., 2007).

It is often said that high throughput approaches are fishing expeditions, or with an elegant euphemism, hypothesis generating efforts. My view is that careful morphology is the most powerful hypothesis generating tool. Examples in our field are the studies on CIS by Niels Skakkebæk (Skakkebaek, 1972) and our own work exploring the initiation of Type II germ cell tumors in dysgenetic gonads mentioned earlier.

\section{How do you think will the (likely) close interaction between Genes and Environment related to GCT development be elucidated to your opinion?}

This is rather a question for you to answer. However, as far as I can see, it involves meticulous epidemiological studies in different ethnic groups. These should be combined with high throughput genetic analysis of these populations, and of their tumors. Last but not least, it takes thorough pathology of the involved tumors. In short: meticulous genotyping and phenotyping.

The testicular dysgenesis hypothesis proposed by Skakkebæk and co-workers is a nice example of such meticulous multidisciplinary research. To be honest I am a believer in testicular dysgenesis syndrome (TDS), and the role of hormone disruptors in the causation of Type II tumors of the testis (Skakkebaek et al., 2003). We are beginning to understand some of the interactions of genes and environment, or in your favorite term: genvironment.

\section{What do you think will be the role of a pathologist in the (future) diagnosis and treatment of GCTs?}

Proper pathological typing and staging of primary tumors and metastatic lesions still is, and will remain essential for clinicians to decide on proper therapy of their patients. Angio-invasiveness for example is a morphologic feature that predicts retroperitoneal metastases in stage I tumors. We have found that this feature is not so easy to detect on $\mathrm{H}$ \& $\mathrm{E}$ slides, and that staining for CD31 and D2-40 makes the scoring of angio-invasion more reproducible. It is quite conceivable that targeted expression analysis for markers predicting angio-invasion, will be superior even to immunohistochemistry. In that case the pathologist has to use this molecular approach as an adjunct to morphology. Similarly there will be molecular tests, e.g. for BRAF-mutations and microsatellite instability, that will predict chemotherapy resistance. Also, pathologists can help people in the lab to select the proper cells and tissues for micro-dissection for high throughput approaches.

\section{How is according to you the most optimal facility organized to elucidate the pathogenesis of GCTs?}

In a multidisciplinary fashion, with pathology, (cyto)genetics, molecular biology and cell biology as corner stones, in close interaction with clinicians. Don't forget the importance of a high quality tumor bank. And then there is the need for suitable cell lines and proper animal models. Thus far we have only one seminoma cell line TCam2 (de Jong et al., 2008a), which is unusual because it has a BRAF-mutation and it is more methylated than a decent seminoma cell should be. We definitely need more seminoma cell lines to study the radio-sensitivity of seminoma and to learn more about the phenomenon of reprogramming seminoma cells to pluripotent EC cells.

\section{What would you advice young scientists and clinicians re- garding their career?}

Your question brings to my mind memories of the evening of August 17, 1989. I had invited Ivan Damjanov as one of the speakers at this satellite symposium in Groningen, which I mentioned before. I collected him at his hotel to bring him to the meeting venue. He gave me the mouse teratocarcinoma cell lines which he had brought from Philadelphia, and also the book that he had been reading that night. I have to exhaust myself before I can sleep, he apologized. It was the autobiography of Francis Crick "What Mad Pursuit". Indeed, a most enjoyable book, in which Francis Crick explains how he decided to study the structure of DNA. He went by his "gossip test". He found out that he was gossiping with friends and colleagues about what excited him most. The "gossip test" tells you what really intrigues you, and what you should pursue. Follow Francis Crick's example: apply the gossip test!

\section{References}

ATKIN, N.B. and BAKER, M.C. (1983). i(12p): specific chromosomal marker in seminoma and malignant teratoma of the testis? Cancer Genet Cytogenet 10: 199-204.

BIERMANN, K., GOKE, F., NETTERSHEIM, D., ECKERT, D., ZHOU, H., KAHL, P., GASHAW, I., SCHORLE, H. and BUTTNER, R. (2007). c-KIT is frequently mutated in bilateral germ cell tumours and down-regulated during progression from intratubular germ cell neoplasia to seminoma. J Pathol 213: 311-318.

BIGNELL, G., SMITH, R., HUNTER, C., STEPHENS, P., DAVIES, H., GREENMAN, C., TEAGUE, J., BUTLER, A., EDKINS, S., STEVENS, C. et al., (2006). Sequence analysis of the protein kinase gene family in human testicular germ-cell tumors of adolescents and adults. Genes Chromosom. Cancer 45: 42-46.

CASTEDO, S.M., DE JONG, B., OOSTERHUIS, J.W., IDENBURG, V.J., SERUCA, R., BUIST, J., TE MEERMAN, G.J., SCHRAFFORDT KOOPS, H. and SLEIJFER, D.T. (1989a). Chromosomal changes in mature residual teratomas following polychemotherapy. Cancer Res 49: 672-676.

CASTEDO, S.M., DE JONG, B., OOSTERHUIS, J.W., SERUCA, R., IDENBURG, V.J., DAM, A., TE MEERMAN, G., KOOPS, H.S. and SLEIJFER, D.T. (1989b). Chromosomal changes in human primary testicular nonseminomatous germ cell tumors. Cancer Res 49: 5696-5701.

CASTEDO, S.M., DE JONG, B., OOSTERHUIS, J.W., SERUCA, R., TE MEERMAN, G.J., DAM, A. and SCHRAFFORDT KOOPS, H. (1989c). Cytogenetic analysis of ten human seminomas. Cancer Res 49: 439-443.

CHENG, L., SUNG, M.T., COSSU-ROCCA, P., JONES, T.D., MACLENNAN, G.T., DE JONG, J., LOPEZ-BELTRAN, A., MONTIRONI, R. and LOOIJENGA, L.H. (2007). OCT4: biological functions and clinical applications as a marker of germ cell neoplasia. J Pathol 211: 1-9.

CLARK, A.T., BODNAR, M.S., FOX, M., RODRIQUEZ, R.T., ABEYTA, M.J., FIRPO, M.T. and PERA, R.A. (2004). Spontaneous differentiation of germ cells from human embryonic stem cells in vitro. Hum Mol Genet 13: 727-739.

COOLS, M., WOLFFENBUTTEL, K.P., DROP, S.L., OOSTERHUIS, J.W. and LOOIJENGA, L.H. (2011). Gonadal development and tumor formation at the crossroads of male and female sex determination. Sex Dev 5: 167-180.

DAL CIN, P., DROCHMANS, A., MOERMAN, P. and VAN DEN BERGHE, H. (1989). Isochromosome 12p in mediastinal germ cell tumor. Cancer Genet Cytogenet 42: 243-251.

DAMJANOV, I. and SOLTER, D. (1974). Experimental teratoma. Curr Top Pathol 59: 69-130.

DE BRUIN, T.W., SLATER, R.M., DEFFERRARI, R., GEURTS VAN KESSEL, A., SUIJKERBUIJK, R.F., JANSEN, G., DE JONG, B. and OOSTERHUIS, J.W. (1994) Isochromosome 12p-positive pineal germ cell tumor. Cancer Res 54: 1542-1544.

DE GRAAFF, W.E., OOSTERHUIS, J.W., DE JONG, B., DAM, A., VAN PUTTEN W.L., CASTEDO, S.M., SLEIJFER, D.T. and SCHRAFFORDT KOOPS, H. (1992) Ploidy of testicular carcinoma in situ. Lab Invest 66: 166-168.

DE JONG, J., STOOP, H., GILLIS, A.J., HERSMUS, R., VAN GURP, R.J., VAN DE GEIJN, G.J., VAN DRUNEN, E., BEVERLOO, H.B., SCHNEIDER, D.T., SHERLOCK, J.K. et al., (2008a). Further characterization of the first seminoma cell line 
TCam-2. Genes Chromosom. Cancer 47: 185-196.

DEJONG, J., STOOP, H., GILLIS, A.J., VAN GURP, R.J., VAN DE GEIJN, G.J., BOER, M., HERSMUS, R., SAUNDERS, P.T., ANDERSON, R.A., OOSTERHUIS, J.W. et al. (2008b). Differential expression of SOX17 and SOX2 in germ cells and stem cells has biological and clinical implications. J Pathol 215: 21-30.

DEKKER, I., ROZEBOOM, T., DELEMARRE, J., DAM, A. and OOSTERHUIS, J.W. (1992). Placental-like alkaline phosphatase and DNA flow cytometry in spermatocytic seminoma. Cancer 69: 993-996.

EINHORN, L.H. and DONOHUE, J. (1977). Cis-diamminedichloroplatinum, vinblastine, and bleomycin combination chemotherapy in disseminated testicular cancer. Ann Intern Med 87: 293-298.

EVANS, M.J. and KAUFMAN, M.H. (1981). Establishment in culture of pluripotential cells from mouse embryos. Nature 292: 154-156.

GELDERMAN, W.A., KOOPS, H.S., SLEIJFER, D.T., OOSTERHUIS, J.W. and OLDHOFF, J. (1986). Treatment of retroperitoneal residual tumor after PVB chemotherapy of nonseminomatous testicular tumors. Cancer 58: 1418-1421.

GILLIS, A.J., STOOP, H., BIERMANN, K., VAN GURP, R.J., SWARTZMAN, E., CRIBBES, S., FERLINZ, A., SHANNON, M., OOSTERHUIS, J.W. and LOOIJENGA, L.H. (2011). Expression and interdependencies of pluripotency factors LIN28, OCT3/4, NANOG and SOX2 in human testicular germ cells and tumours of the testis. Int $J$ Androl 34: e160-e174.

GILLIS, A.J., STOOP, H.J., HERSMUS, R., OOSTERHUIS, J.W., SUN, Y., CHEN, C., GUENTHER, S., SHERLOCK, J., VELTMAN, I., BAETEN, J. et al., (2007). High-throughput microRNAome analysis in human germ cell tumours. J Pathol 213: 319-328

HONECKER, F., STOOP, H., MAYER, F., BOKEMEYER, C., CASTRILLON, D.H., LAU, Y.F., LOOIJENGA, L.H. and OOSTERHUIS, J.W. (2006). Germ cell lineage differentiation in non-seminomatous germ cell tumours. J Pathol 208: 395-400.

KANETSKY, P.A., MITRA, N., VARDHANABHUTI, S., LI, M., VAUGHN, D.J., LETRERO, R., CIOSEK, S.L., DOODY, D.R., SMITH, L.M., WEAVER, J. et al., (2009). Common variation in KITLG and at 5q31.3 predisposes to testicular germ cell cancer. Nat Genet 41: 811-815.

KERSEMAEKERS, A.M., HONECKER, F., STOOP, H., COOLS, M., MOLIER, M., WOLFFENBUTTEL, K., BOKEMEYER, C., LI, Y., LAU, Y.F., OOSTERHUIS, J.W. et al., (2005). Identification of germ cells at risk for neoplastic transformation in gonadoblastoma: an immunohistochemical study for OCT3/4 and TSPY. Hum Pathol 36: 512-521.

KIM, J.B., GREBER, B., ARAUZO-BRAVO, M.J., MEYER, J., PARK, K.I., ZAEHRES, H. and SCHOLER, H.R. (2009). Direct reprogramming of human neural stem cells by OCT4. Nature 461: 649-643

LOOIJENGA, L.H., DE LEEUW, H., VAN OORSCHOT, M., VAN GURP, R.J., STOOP, H., GILLIS, A.J., DE GOUVEIA BRAZAO, C.A., WEBER, R.F., KIRKELS, W.J., VAN DIJK, T. et al., (2003a). Stem cell factor receptor (c-KIT) codon 816 mutations predict development of bilateral testicular germ-cell tumors. Cancer Res 63: 7674-7678.

LOOIJENGA, L.H., HERSMUS, R., GILLIS, A.J., PFUNDT, R., STOOP, H.J., VAN GURP, R.J., VELTMAN, J., BEVERLOO, H.B., VAN DRUNEN, E., VAN KESSEL, A.G. et al., (2006). Genomic and expression profiling of human spermatocytic seminomas: primary spermatocyte as tumorigenic precursor and DMRT1 as candidate chromosome 9 gene. Cancer Res 66: 290-302.

LOOIJENGA, L.H., OLIE, R.A., VAN DER GAAG, I., VAN SLUIJS, F.J., MATOSKA, J., PLOEM-ZAAIJER, J., KNEPFLE, C. and OOSTERHUIS, J.W. (1994). Seminomas of the canine testis. Counterpart of spermatocytic seminoma of men? Lab Invest 71: 490-496.

LOOIJENGA, L.H., STOOP, H., DE LEEUW, H.P., DE GOUVEIA BRAZAO, C.A., GILLIS, A.J., VAN ROOZENDAAL, K.E., VAN ZOELEN, E.J., WEBER, R.F., WOLFFENBUTTEL, K.P., VAN DEKKEN, H. et al., (2003b). POU5F1 (OCT3/4) identifies cells with pluripotent potential in human germ cell tumors. Cancer Res 63: 2244-2250.

MATSUI, Y., ZSEBO, K. and HOGAN, B.L. (1992). Derivation of pluripotential embryonic stem cells from murine primordial germ cells in culture. Cell 70: 841-847.

MAYER, F., HONECKER, F., LOOIJENGA, L.H. and BOKEMEYER, C. (2003). Towards an understanding of the biological basis of response to cisplatin-based chemotherapy in germ-cell tumors. Ann Oncol 14: 825-832.

MAYER, F., WERMANN, H., ALBERS, P., STOOP, H., GILLIS, A.J., HARTMANN, J.T., BOKEMEYER, C.C., OOSTERHUIS, J.W., LOOIJENGA, L.H. and HONECKER, F. (2011). Histopathological and molecular features of late relapses in non-seminomas. BJU Int 107: 936-943.

MCGRATH, J. and SOLTER, D. (1983a). Nuclear transplantation in mouse embryos. $J$ Exp Zool 228: 355-362.

MCGRATH, J. and SOLTER, D. (1983b). Nuclear transplantation in the mouse embryo by microsurgery and cell fusion. Science 220: 1300-1302.

OOSTERHUIS, J.W. (1978). Lymphatic migration after laser surgery. Lancet1:446-447.

OOSTERHUIS, J.W., ANDREWS, P.W., KNOWLES, B.B. and DAMJANOV, I. (1984). Effects of cis-platinum on embryonal carcinoma cell lines in vitro. Int $J$ Cancer 34: 133-139.

OOSTERHUIS, J.W., BERLO VAN, R.J., JONG, D.B., DAM, A., BUIST, J., TAMMINGA, R. and ZWIERSTRA, R.P. (1993). Sacral teratoma with late recurrence of yolk sac tumor: human counterpart of embryo- or yolk sac derived teratoma? $J$ Urol Pathol 1: 257-267.

OOSTERHUIS, J.W., CASTEDO, S.M. and DE JONG, B. (1990). Cytogenetics, ploidy and differentiation of human testicular, ovarian and extragonadal germ cell tumours. Cancer Surv 9: 320-332.

OOSTERHUIS, J.W., CASTEDO, S.M., DE JONG, B., CORNELISSE, C.J., DAM, A., SLEIJFER, D.T. and SCHRAFFORDT KOOPS, H. (1989). Ploidy of primary germ cell tumors of the testis. Pathogenetic and clinical relevance. Lab Invest60: 14-21.

OOSTERHUIS, J.W. and DAMJANOV, I. (1983). Treatment of primary embryo-derived teratocarcinomas in mice with cis-diamminedichloroplatinum. Eur J Cancer Clin Oncol 19: 695-699.

OOSTERHUIS, J.W., DE JONG, B., CORNELISSE, C.J., MOLENAAR, I.M., MEIRING, A., IDENBURG, V., KOOPS, H.S. and SLEIJFER, D.T. (1986). Karyotyping and DNA flow cytometry of mature residual teratoma after intensive chemotherapy of disseminated nonseminomatous germ cell tumor of the testis: a report of two cases. Cancer Genet Cytogenet 22: 149-157.

OOSTERHUIS, J.W., KERSEMAEKERS, A.M., JACOBSEN, G.K., TIMMER, A. STEYERBERG, E.W., MOLIER, M., VAN WEEREN, P.C., STOOP, H. and LOOIJENGA, L.H. (2003). Morphology of testicular parenchyma adjacent to germ cell tumours. An interim report. APMIS 111: 32-40; discussion 41-2.

OOSTERHUIS, J.W. and LOOIJENGA, L.H. (1993). The biology of human germ cell tumours: retrospective speculations and new prospectives. Eur Urol 23: 245-250.

OOSTERHUIS, J.W. and LOOIJENGA, L.H. (2005). Testicular germ-cell tumours in a broader perspective. Nat Rev Cancer 5: 210-222

OOSTERHUIS, J.W., LOOIJENGA, L.H., VAN ECHTEN, J. and DE JONG, B. (1997) Chromosomal constitution and developmental potential of human germ cell tumors and teratomas. Cancer Genet Cytogenet 95: 96-102.

OOSTERHUIS JW, P.S., SMIT VTHBM, STOOP J, LOOIJENGALHJ, ELZEVIER HW, OSANTO S. (2013). Patient with two secondary somatic-type malignancies in a late recurrence of a testicular non-seminoma: illustration of potential and flaw of the cancer stem cell therapy concept. Int. J. Dev. Biol. (doi: 10.1387/ijdb.130141jo)

OOSTERHUIS, J.W., STOOP, H., DOHLE, G., BOELLAARD, W., VAN CASTEREN N., WOLFFENBUTTEL, K. and LOOIJENGA, L.H. (2011). A pathologist's view on the testis biopsy. Int $J$ Androl 34: e14-e19; discussion e20.

OOSTERHUIS, J.W., STOOP, H., HONECKER, F. and LOOIJENGA, L.H. (2007), Why human extragonadal germ cell tumours occur in the midline of the body: old concepts, new perspectives. Int J Androl 30: 256-263; discussion 263-4.

OOSTERHUIS, J.W., SUURMEYER, A.J., SLEYFER, D.T., KOOPS, H.S., OLDHOFF, J. and FLEUREN, G. (1983). Effects of multiple-drug chemotherapy (cis-diamminedichloroplatinum, bleomycin, and vinblastine) on the maturation of retroperitoneal lymph node metastases of nonseminomatous germ cell tumors of the testis. No evidence for De Novo induction of differentiation. Cancer 51: 408-416.

RAPLEY, E.A., TURNBULL, C., AL OLAMA, A.A., DERMITZAKIS, E.T., LINGER, R., HUDDART, R.A., RENWICK, A., HUGHES, D., HINES, S., SEAL, S. et al., (2009). A genome-wide association study of testicular germ cell tumor. Nat Genet 41: 807-810.

ROSENBERG, C., MOSTERT, M.C., SCHUT, T.B., VAN DE POL, M., VAN ECHTEN, J., DE JONG, B., RAAP, A.K., TANKE, H., OOSTERHUIS, J.W. and LOOIJENGA L.H. (1998). Chromosomal constitution of human spermatocytic seminomas: comparative genomic hybridization supported by conventional and interphase cytogenetics. Genes Chromosom. Cancer 23: 286-291.

ROSENBERG, C., VAN GURP, R.J., GEELEN, E., OOSTERHUIS, J.W. and LOOIJENGA, L.H. (2000). Overrepresentation of the short arm of chromosome 12 is related to invasive growth of human testicular seminomas and nonseminomas. Oncogene 19: 5858-5862. 
SKAKKEBAEK, N.E. (1972). Possible carcinoma-in-situ of the testis. Lancet2:516-517.

SKAKKEBAEK, N.E., BERTHELSEN, J.G., GIWERCMAN, A. and MULLER, J. (1987). Carcinoma-in-situ of the testis: possible origin from gonocytes and precursor of all types of germ cell tumours except spermatocytoma. Int J Androl 10: 19-28.

SKAKKEBAEK, N.E., HOLM, M., HOEI-HANSEN, C., JORGENSEN, N. and RAJPERTDE MEYTS, E. (2003). Association between testicular dysgenesis syndrome (TDS) and testicular neoplasia: evidence from 20 adult patients with signs of maldevelopment of the testis. APMIS 111: 1-9; discussion 9-11.

SOLTER, D. (2006). From teratocarcinomas to embryonic stem cells and beyond: a history of embryonic stem cell research. Nat Rev Genet 7: 319-327.

STANG, A., TRABERT, B., WENTZENSEN, N., COOK, M.B., RUSNER, C., OOSTERHUIS, J.W. and MCGLYNN, K.A. (2012). Gonadal and extragonadal germ cell tumours in the United States, 1973-2007. Int J Androl 35: 616-625.

STOTER, G., SLEIJFER, D.T., VENDRIK, C.P., SCHRAFFORDT KOOPS, H., STRUYVENBERG, A., VAN OOSTEROM, A.T., BROUWERS, T.M. and PINEDO, H.M. (1979). Combination chemotherapy with cis-diammine-dichloro-platinum, vinblastine, and bleomycin in advanced testicular non-seminoma. Lancet 1: 941-945.

SURANI, M.A., BARTON, S.C. and NORRIS, M.L. (1986). Nuclear transplantation in the mouse: heritable differences between parental genomes after activation of the embryonic genome. Cell 45: 127-136.

TAN, C. and SCOTTING, P.J. (2013). Stem cell research points the way to the cell of origin for intracranial germ cell tumours. $J$ Pathol 229: 4-11.

THOMSON, J.A., ITSKOVITZ-ELDOR, J., SHAPIRO, S.S., WAKNITZ, M.A., SWIERGIEL, J.J., MARSHALL, V.S. and JONES, J.M. (1998). Embryonic stem cell lines derived from human blastocysts. Science 282: 1145-1147.

VAN BERLO, R.J., OOSTERHUIS, J.W., SCHRIJNEMAKERS, E., SCHOOTS, C.J., DE JONG, B. and DAMJANOV, I. (1990). Yolk-sac carcinoma develops spontaneously as a late occurrence in slow-growing teratoid tumors produced from transplanted 7-day mouse embryos. Int J Cancer 45: 153-155.

VAN GURP, R.J., OOSTERHUIS, J.W., KALSCHEUER, V., MARIMAN, E.C. and LOOIJENGA, L.H. (1994). Biallelic expression of the H19 and IGF2 genes in human testicular germ cell tumors. J Natl Cancer Inst 86: 1070-1075.

WALT, H., OOSTERHUIS, J.W. and STEVENS, L.C. (1993). Experimental testicular germ cell tumorigenesis in mouse strains with and without spontaneous tumours differs from development of germ cell tumours of the adult human testis. Int $J$ Androl 16: 267-271. 


\section{Further Related Reading, published previously in the Int. J. Dev. Biol.}

Identification of side population cells in mouse primordial germ cells and prenatal testis Maria-Lucia Scaldaferri, Stefania Fera, Laura Grisanti, Massimo Sanchez, Mario Stefanini, Massimo De Felici and Elena Vicini Int. J. Dev. Biol. (2011) 55: 209-214

Differentiation of mouse primordial germ cells into female or male germ cells N Nakatsuji and S Chuma

Int. J. Dev. Biol. (2001) 45: 541-548

The role of stem cell factor and of alternative c-kit gene products in the establishment, maintenance and function of germ cells C Sette, S Dolci, R Geremia and P Rossi Int. J. Dev. Biol. (2000) 44: 599-608

Regulation of primordial germ cell development in the mouse M De Felici

Int. J. Dev. Biol. (2000) 44: 575-580

IGF-I, IGF-II and insulin promote differentiation of spermatogonia to primary spermatocytes in organ culture of newt testes

Y Nakayama, T Yamamoto and S I Abé

Int. J. Dev. Biol. (1999) 43: 343-347

5 yr ISI Impact Factor $(2011)=2.959$
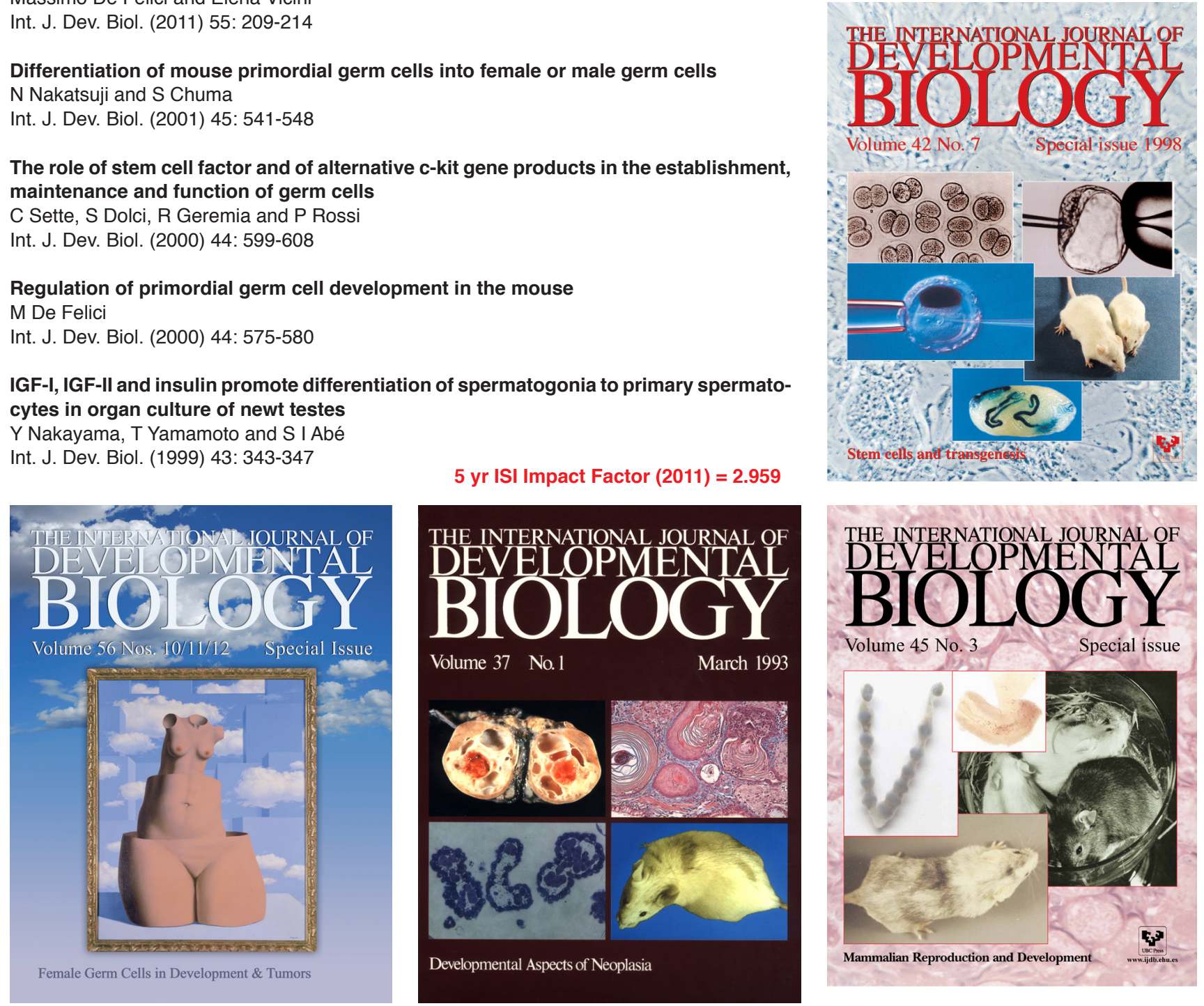